\title{
A Primo használata a Magyar Tudományos Akadémia Könyvtár és Információs Központban
}

\section{A rendszer általános jellemzői}

A Primo szolgáltatás az Ex Libris, a ProQuest Company ${ }^{l}$ cégegyüttes portfóliójának része. A rendszer magyarországi forgalmazója és egyben a terméktámogatást adó cége az Ex-Lh Kft. ${ }^{2}$

A Primot jellemzően felhőalapú szolgáltatásként vehetik igénybe az egyes könyvtárak és információ-közvetítő intézmények online szolgáltatásaik fejlesztése érdekében. A szoftver a discovery and delivery rendszerek körébe tartozik, és azok összes kutatástámogató megoldásával rendelkezik. Ezen rendszerek legföbb jellemzője, hogy különbözö intelligens keresési technikák és eszközök használata révén minden eddiginél nagyobb hangsúlyt fektetnek az információ feltárásának és felfedezésének mozzanatára, függetlenül annak hordozójától, illetve ezzel párhuzamosan - mintegy az információkereső folyamat eredményeként - ,gondoskodnak” a könyvtár jogosultságainak megfelelően az információt tartalmazó dokumentumváltozatok (metaadat, hangzó-, képi-, multimédia-dokumentumok, absztraktok és teljes szövegek) felhasználó elé történő „szállításáról" is. További fontos tulajdonságuk az ún. egypontos keresés biztosítása, amely révén lehetőség van egyidejüleg elérni a könyvtár összes gyüjteményét (legyen szó akár a könyvtár online katalógusáról, a könyvtár által előfizetett adatbázisokról, illetve annak különböző digitális vagy elektronikus gyüjteményeiröl). Többségük központi indexszel rendelkezik (ez a Primo esetében a PCI - Primo Central Index), amely nemcsak több millió közvetlen rekordkapcsolatot jelent, hanem jelentősen meggyorsítja a keresés folyamatát is. Általában a szabványok széleskörü támogatása (pl.: MARC, DC, OpenSearch, OAI-PMH stb.) jellemzi öket, amely révén mintegy platform-független szolgáltatásként a legkülönfélébb rendszerekkel való együttmúködést tudják megvalósítani. ${ }^{3}$ Fontos jellemzőjük a találatok relevancia szerinti rendezése, továbbá az úgynevezett facetták alkalmazásával az adott esetben több tízezres találati halmaz különböző szempontok szerinti rendezése, szükítése, illetve ezt felhasználva új keresések ajánlása a felhasználóknak. Természetesen mindezen szolgáltatásokat felhasználóbarát és modern felületeken nyújtják, teret engedve a közvetlen felhasználói közremükö-

\footnotetext{
${ }^{1}$ http://www.exlibrisgroup.com (Utolsó letöltés: 2016. október 9.)

${ }^{2}$ http://www.ex-lh.hu/site/index.php/HU (Utolsó letöltés: 2016. október 9.)

${ }^{3}$ Ez az MTA KIK esetében - ahogy arról még lesz szó - az ALEPH, SFX, MetaLib, ADAM, JaDoX és EPrints szoftverek ,együttkezelését” jelenti.
} 
désnek is, például a rekordokhoz kapcsolódó kommentek, értékelések, címkézések formájában. ${ }^{4}$

\section{A Primo bevezetése az MTA KIK-ben}

A rendszer elindítására könyvtárunkban 2015 novemberében került sor, amelyet azonban mintegy 1 éves előkészítő fázis előzött meg. Ennek során a könyvtári igények megfogalmazása bizottsági munka keretében folyt, amelynek tagjai az Olvasószolgálati és Szakinformatikai Osztály munkatársai, illetve a könyvtári honlap felelősei voltak. Az igények közvetítése az Ex-Lh Kft. felé, a cég konfigurációt végző munkatársaival való folyamatos kapcsolattartás és a rendszerdokumentáció megismerése a Szakinformatikai Osztály feladata volt. A szükséges tesztelésekre kibővített munkatársi körben - törekedve lehetöleg minél több, elsősorban olvasószolgálatos kolléga bevonására - került sor.

Alapvetően két területre koncentrált a munka: egyrészt a formai-technikai problémák megoldására, másrészt a kívánatos tartalmi működés kialakítására.

A formai-technikai problémák közül elsőként a Primo kezdőképernyő tartalmának és megjelenésének kialakítására került sor. Megegyezés született arról, hogy a Primo lesz a könyvtár szolgáltatási felülete. Ennek kapcsán meghatározásra került, hogy az MTA KIK honlapjáról mik kerülnek (önállóan vagy megosztva) át az új felületre: a könyvtári szolgáltatásokkal kapcsolatos hírek, aktualitások mellett a dokumentum-előkészítés (lefoglalás) igénylése, az adatbázis, e-folyóirat, e-könyv A-Z listák, a keresési csoportok (scope-ok) részletes leírásai és egyéb tájékozódást, keresést segítő funkciók (linkgyüjtemény, könyvajánló) kaptak helyet az oldalon. Fontos alapelv volt, hogy az új felület színvilágának, dizájnelemeinek meg kell egyezniük a könyvtári honlap kialakításával. Ennek megfelelöen lettek megtervezve a honlap fejlécének képi elemei is. Tudva, hogy napjainkban egy jól megválasztott elnevezés nagyban befolyásolhatja egy rendszer bevezetésének sikerességét, csak hosszas mérlegelés után történt meg a névadás. A MTA KIK Primoja végül a metakereső szó és a könyvtár nevének rövidítéséből a $\mathrm{M}[\mathrm{e}] \mathrm{TAK}$ elnevezést kapta.

A munka következő szakaszában a szerkezeti elemek igazítására, a rendszer működése során használt üzenetek hibáinak javítására, a fordítások véglegesítésére, a különböző karakterkódolási problémák kiküszöbölésére került sor. A különböző rendszerfunkciók (beállítások, mentések, értesítések) és a kényelmi szolgáltatások (pl. e-polc használat, elöjegyzés) müködésének ellenőrzése sem maradhatott el.

Tartalmi szempontból az első lépés annak meghatározása volt, hogy mely gyüjteményeket, adatbázisokat, és milyen csoportosításban akarunk kereshetővé

${ }^{4}$ A közös jellemzők részletes ismertetését 1.: Dávid Adrienn: Hol tart a következő generációs katalógus? 260 amerikai és kanadai egyetemi könyvtár online katalógusának vizsgálatát bemutató tanulmány. = Tudományos és Müszaki Tájékoztatás, 62. évf. 2015. 1. sz. 28-31. 
tenni a Primoval. A könyvtári katalógus és repozitórium (REAL - EPrints), valamint az elöfizetett adatbázisok mellett az akadémiai intézetek, az országos, nagy könyvtárak katalógusaiból, valamint az Akadémiai Könyvtár és partnerei által létrehozott digitális Képkönyvtár (JaDoX) anyagaiból került kialakításra egy-egy keresőcsoport (scope). Ezek mellett természetesen az összes gyüjteményben egyszerre történő keresésre is lehetőség van a Keresés mindenben opcióval. Folyamatos tesztelésekkel ellenőriztük az adatok megjelenítésének pontosságát, azok könyvtári adatbázissal való egyezőségét, a megfelelő indexelést és visszakereshetőséget. Az ellenőrzési folyamathoz kapcsolódóan fontos lépés volt a Primo-rekordok belső szerkezetének megismerése. A rendszer a beérkező, különböző szabványok alapján készült, eltérő felépítésű külső rekordokból egy egységes szerkezetủ belső, úgynevezett PNX-rekordot ${ }^{5}$ hoz létre, $\mathrm{s}$ ezt használja aztán az adatmegjelenítés és az indexelés során. A rekordok szekciókból, ${ }^{6}$ a szekciók adatmezőkből épülnek fel, az adatmezők pedig minden nagy szabvány adatstruktúrájával megfeleltetésben vannak ('́gy például a MARC21 szabvány esetében is a leggyakrabban használt MARC-mezők megfeleltetését tartalmazza a rendszer). Ezenfelül minden szekcióban további $50 \mathrm{db}$ úgynevezett lokális mező definiálható az esetleges egyedi adatmegjelenítésre és indexelési igényekhez. Az MTA KIK-ben a mezőmegfeleltetések ellenőrzése és finomítása még folyamatban van, hogy minél pontosabb és hatékonyabb megjelenítést és visszakereshetőséget biztosíthassunk. Az alábbi táblázatban néhány, könyvtárunkban alkalmazott mezőpárosítás látható:

\begin{tabular}{|l|l|l|}
\hline \multicolumn{1}{|c|}{ Szekció } & \multicolumn{1}{|c|}{ PNX-adatmezö } & \multicolumn{1}{c|}{ MARC 21 adatmezö } \\
\hline Display & Creator & 100 abcdejqu; 110 abcde; 111 abcdn \\
\hline & Title & $245 \# \# \$$ abfgknp; 130\#\#adfklmnoprs \\
\hline & Subject & minden $6 \mathrm{xx}$ mező \\
\hline Search & creatorcontrib & $100,110 \ldots 245 \$ \$ \mathrm{c}, 505,508,7 \mathrm{xx}, 8 \mathrm{xx}$ \\
\hline & Description & $520 \$ \$ \mathrm{a}$ \\
\hline & ISBN & $020 \mathrm{az}$ \\
\hline Facets & Language & $008 / 35-37 .+041 \$ \$ \mathrm{a}, \mathrm{d}, \mathrm{e}$ \\
\hline Browse & Author & $1 \mathrm{xx}, 7 \mathrm{xx}, 8 \mathrm{xx}$ \\
\hline
\end{tabular}

1. táblázat. PNX- MARC-mezők megfeleltetése (MTA KIK Primo)

${ }^{5}$ A rövidítés feloldása: Primo Normalized XML. A PNX-rekordot egy showPnx nevü Chrome-bővítmény segítségével lehet megjeleníteni. A bővítmény letölthető pl. innen: https:// chrome.google.com/webstore/detail/showpnx-for-exlibris-prim/nnibcklgecdkccooecjdoadbkifnm djc\# (2016. október 4.)

${ }^{6}$ Az egyes szekciók a bibliográfiai rekordokban rögzített adatok különböző felhasználási „területeit” jelölik (pl.: Display=Részletes megjelenítés, Search= a Keresési index, Browse= Böngészés, Facets $=$ Facetták stb.) 
A tesztelési időszakban jó néhány újszerü - a „hagyományos” könyvtári katalógustól eltérö - megoldással és nehezen kezelhető hibával is szembe kellett néznünk. A teljesség igénye nélkül néhány ezek közül: Primoban a könyvtári katalógus indexelése nem a könyvtári rendszerben (Aleph) kialakított paraméterek szerint történik; ${ }^{7}$ problémát jelentett a bibliográfiai rekordokhoz kapcsolódó digitális rész-objektumok (címlap, tartalomjegyzék), ill. MetaLib-es kapcsolatokon alapuló rekordkapcsolatok (katalógustétel) „teljes szövegként” való megjelenítése; ${ }^{8}$ a 856-os MARC-mező eltérő müködése az Aleph-ben és a Primo-ban; ${ }^{9}$ egyelöre még mindig nem megoldott a kikölcsönzött és a nem-hozzáférhető státusz egy speciális változatának ugyanazon kategóriába sorolása; ${ }^{10}$ a dokumentumtípusok meghatározásának forrása nem a katalógusrekordok FMT-mezője, hanem az LDR és 008-as mezők, így a Primoban való helyes megjelenítés érdekében újra kell gondolni azok használatát a katalogizálás során.

A bevezetési szakasz előkészítési és tesztelési munkái nagyon sok új ismeretet és tapasztalatot adtak a könyvtárosoknak. Fontos tanulság volt, hogy a rendszerben rejlő lehetőségek minél nagyobb fokú kihasználása érdekében a könyvtárosoknak törekedniük kell a rendszerrel kapcsolatos fellelhetö technikai anyagok megismerésére, az alapos, sokrétü tesztelésre, és ezek alapján a folyamatos konzultációra a szolgáltató cég munkatársaival.

\section{A Primo müködése az MTA KIK-ben}

A tesztelési időszak végére sikerült az elképzeléseinknek megfelelő megjelenítést és - néhány hibától eltekintve - megfelelő, a szolgáltatásokat hatékonyan támogató müködést kialakítani. A megmaradt hibák javításán, valamint a felmerülő szolgáltatásbővítő igények kezelésén folyamatosan dolgozunk. Az alábbiakban a müködés bemutatásán keresztül szeretném ismertetni az elért eredményeket.

Az előzőekben már szó volt a nyitóoldal kialakításának koncepciójáról és annak szerkezetéről. A müködés szempontjából a kezdőoldal legfontosabb eleme a felső harmadban található keresődoboz. A felhasználónak itt van lehetősége egyetlen keresőmezőben lekérdezni az egyes keresőcsoportokban meghatározott adatbázisokat (vagy akár a teljes gyüjteményt: Keresés mindenben). A keresőkifejezés(ek) megadása - amely során az ismert logikai operátorokat,

${ }^{7}$ A keresést nem az ALEPH index-táblái vezérlik, hanem a Primo saját indexelési eljárása, ami a fentebb már tárgyalt PNX-MARC21 megfeleltetésen alapul.

${ }^{8}$ A rész-objektumok vonatkozásában a problémát sikerült kezelni, de a távoli katalógusok tételeire mutató kapcsolatok továbbra is „teljes szövegként” jelennek meg a Primo felületén.

${ }^{9}$ ALEPH-ben a 856-os mező első indikátorával (4) jelezni lehet, hogy a mezöben megjelenített webcím a 'http' protokollt használja, így azt már a linkbe nem kellett beleírni. A Primo-nak viszont „szüksége” van a protokoll megjelenítésére a címben, mert anélkül hibás címként értelmezi.

${ }^{10}$ Kiadva innen státusban jelenik meg mindkettő. A probléma megoldásához a példányrekordokban használatos feldolgozási státuszok szerepét kell meghatározni a Primo számára. 
illetve helyettesítő karaktereket is használhatja -, és a megfelelő scope ${ }^{11}$ kiválasztása után indulhat a keresés.

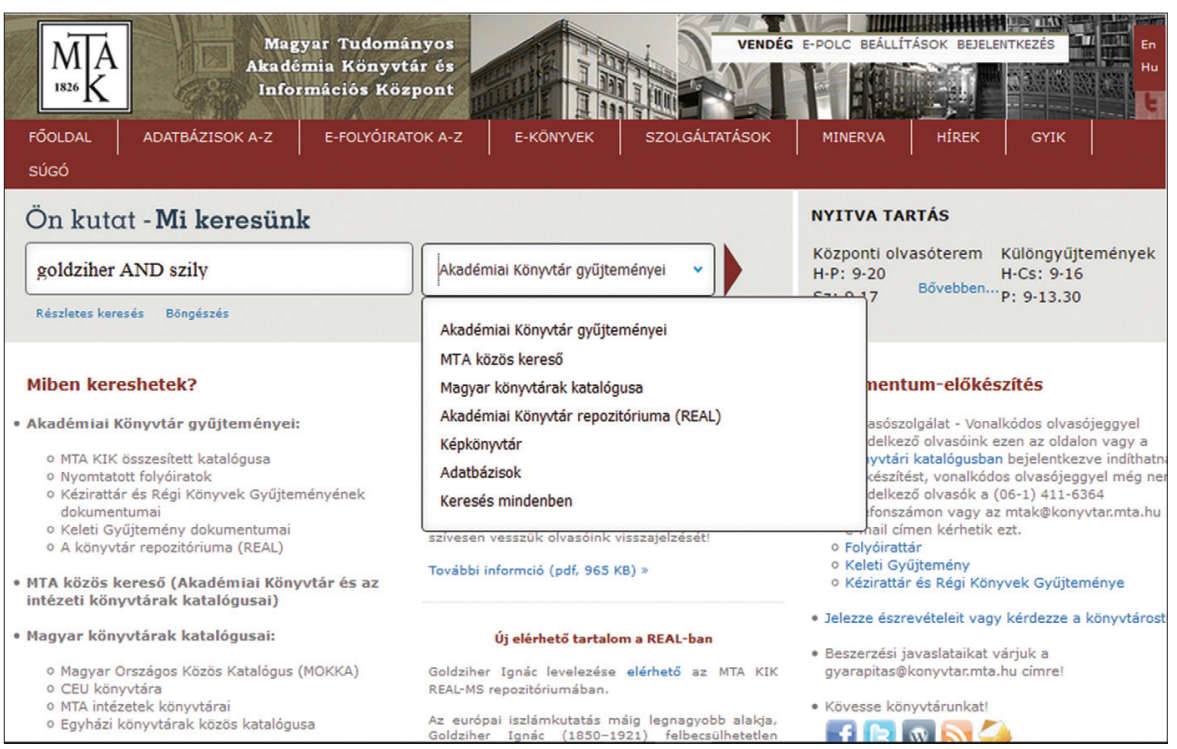

1. ábra. A nyitóoldal és a keresődoboz

Az egyszerü keresés mellett lehetőség van összetett és böngészö lekérdezésre is. A részletes keresésnél már több mezőt használhatunk egyidejüleg, továbbá különböző szükítési lehetőségek állnak rendelkezésünkre. ${ }^{12}$

\begin{tabular}{|c|c|c|}
\hline mint szerzö/alkotó $\vee$ mely ezz tartalmazza: $\checkmark$ kosáry & $\begin{array}{l}\text { Publikáció } \\
\text { dátuma: }\end{array}$ & $E$ Elozzö 20 év \\
\hline$\checkmark$ mely ezt tartalmazza: $\checkmark$ magyar & Anyagtipus & Könyvek \\
\hline \multirow[t]{4}{*}{$\checkmark$ mely ezt tartalmazza: $\checkmark$ ] } & Nyelv: & Magyar \\
\hline & Kezdôdátum: & Nap $\vee$ Hónap $\vee$ Év $(0000$ \\
\hline & Záródátum: & Nap $\vee \checkmark$ Hónap $v$ Év $(\infty \infty \infty)$ \\
\hline & Keresés itt: & Akadémiai Könyvtár gyüjteményei $v$ \\
\hline Egyszerũ keresés & & \\
\hline
\end{tabular}

\section{2. ábra. A részletes keresés mezői}

${ }^{11}$ Az Akadémiai Könyvtár gyüjteményei csoport az Aleph-katalógus, ill. a REAL dokumentumait tartalmazza, míg a REAL ezenkívül külön csoportként is szerepel. Az Aleph-adatok frissítése minden éjszaka megtörténik. A Primo Dublin Core formátumú exportként veszi át a REALrekordokat. Az Adatbázisok csoport közvetlenül a PCI-t (Primo Central Index) használja, míg a többi keresőcsoport a MetaLib nevü rendszeren keresztül, annak beállításait használva érkezik a Primoba.

${ }^{12}$ Esetükben, ahogy azt a 2. ábra is mutatja, három keresőmezó áll a felhasználók rendelkezésére, továbbá a publikáció dátumára, anyagtípusára, nyelvére is szükíthetünk. Emellett természetesen keresőcsoportot is választhatunk. 
Böngészésnél négy listából (tárgyszó, szerző, cím és raktári szám) választhatunk, majd a lista tételeire kattintva juthatunk a részletes leíráshoz és a példányadatokhoz.

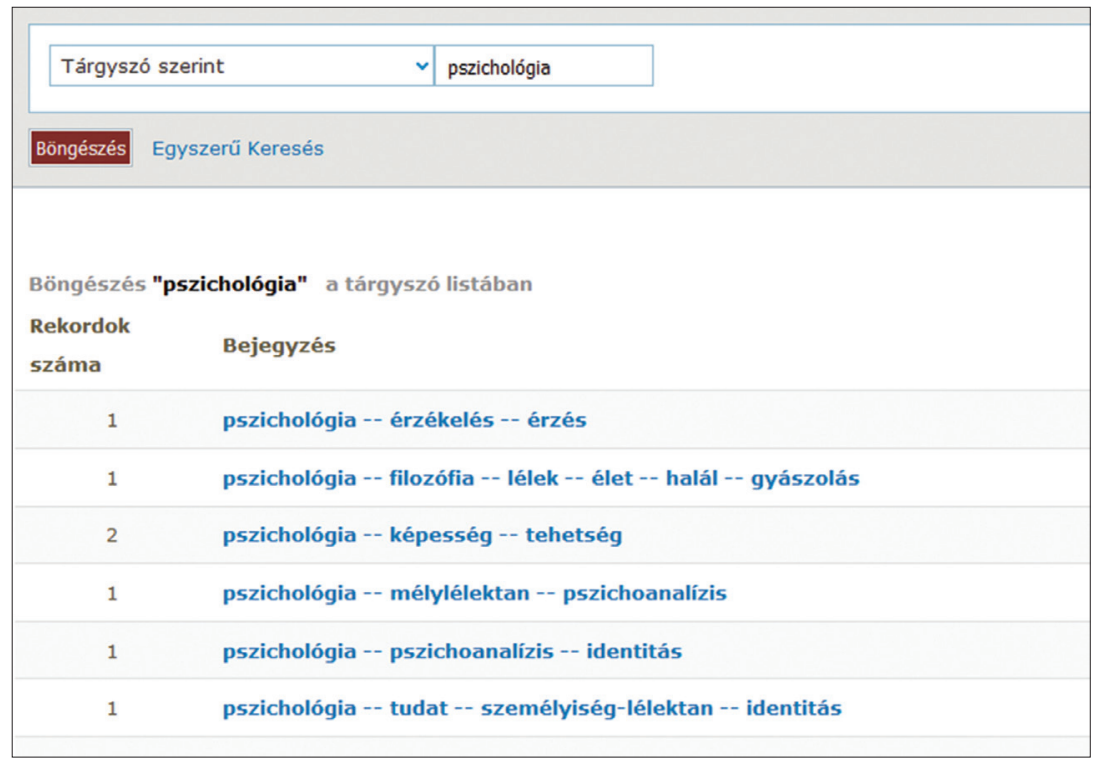

\section{3. ábra. Böngészés}

A keresés után elsőként egy rövid formátumú találati listában jeleníti meg a rendszer a releváns rekordokat. A lista tetején a keresőkifejezéssel kapcsolatos találatszám mellett az egy oldalon megjelenő tételek számát láthatjuk. ${ }^{13} \mathrm{~A}$ találatok rendezésének elve a relevancia, a fontosság. ${ }^{14}$ A Primoban a relevancia bonyolult algoritmusok alapján határozódik meg, amelynek bizonyos vonatkozásait befolyásolni lehet a MARC-mezők egymáshoz való viszonya alapján. ${ }^{15} \mathrm{~A}$ találati listában az egyes tételek legfontosabb bibliográfiai adatai jelennek meg - szerző, cím, kiadási év - a dokumentumtípusra utaló ikonokkal együtt. Közvetlenül alattuk

${ }^{13} \mathrm{Az}$ egy oldalon megjelenő találatok száma az összes keresőcsoport vonatkozásában $50 \mathrm{db}$. A MetaLibes forrásokat tartalmazó keresőcsoportok esetében ezen túl - relevancia alapján - még egy úgynevezett „első körös” találati kört is meghatároz a rendszer, amely minden érintett adatbázisból maximum $30 \mathrm{db}$ rekordot tartalmaz. Természetesen lehetőség van ezen találati halmaz bővítésére is a Több találat megjelenitése? gombra kattintva. Az új tételek külön jelzést kapnak a találati listában (4. ábra).

${ }^{14}$ Ezenkívül dátum, szerző és cím szerinti rendezésre van lehetőségünk.

${ }^{15}$ Az úgynevezett boostingolással (vagy boosterolással) különbözö értékeket lehet adni a releváns MARC-mezőknek (Szerző, Cím, Tárgyszó), amivel befolyásolni lehet egy rekord - a keresőkifejezés és az adott MARC-mező egyezősége alapján - találati listában elfoglalt helyét. Ezenkívül lehetőség van a helyi rekordok előnybe részesítésére is a távoli tételekkel szemben. 
látható a mü elérhetőségére vonatkozó információ (pl.: Hozzáférhető itt, Kiadva, Online forrás). A könnyebb átláthatóság és kezelhetőség érdekében a rendszer a részben megegyező adatokkal rendelkező rekordokat csoportosítja. ${ }^{16} \mathrm{~A}$ csoportosított rekordokból a találati listában egy kerül kiemelésre, a többit a További változatok (vagy Verziók megtekintése) gombokra kattintva lehet megnyitni (5. ábra).

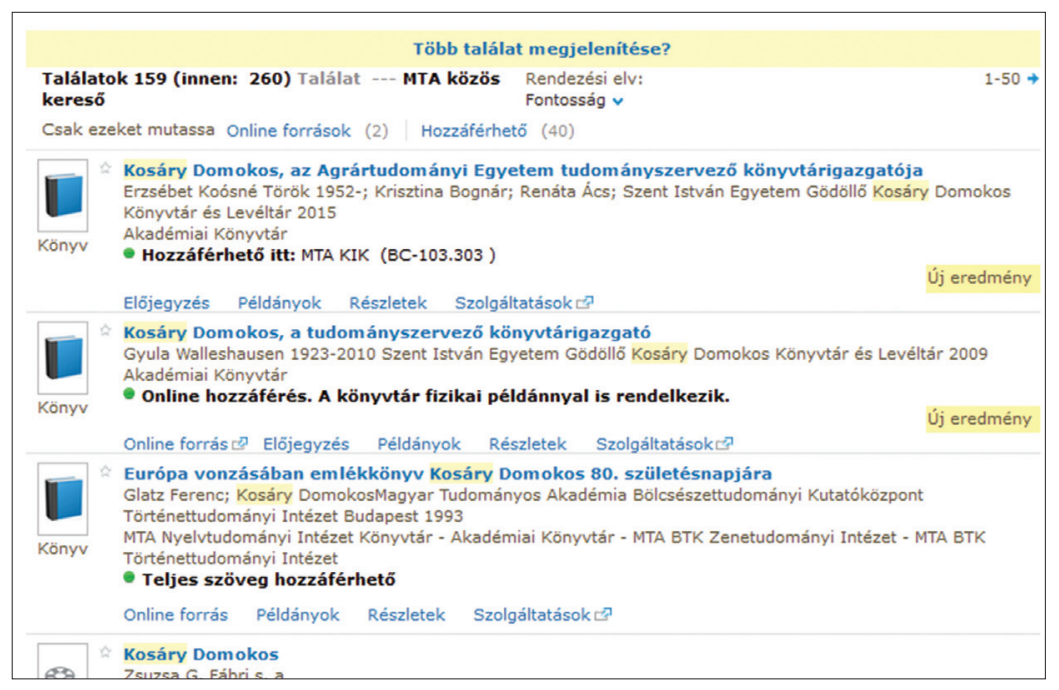

4. ábra. Első körös találati lista

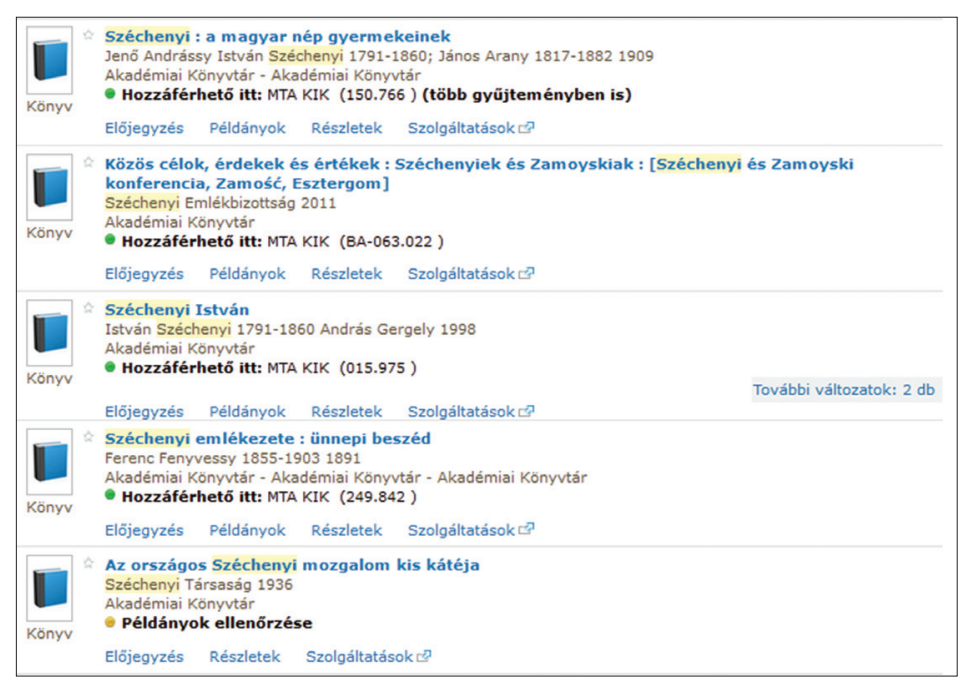

\section{5. ábra. Találati lista - csoportosítás}

${ }^{16}$ Primoban a csoportosítás az FRBR-modell (Functional Requirements for Bibliographic Records) alapelvei szerint történik. 
A fentiek mellett további szolgáltatások érhetők el a rövid formátumú megjelenítésből. A Részletek alatt egyrészt a bővebb bibliográfiai leírást találjuk, ${ }^{17}$ másrészt a Linkek ablakból a könyvtári katalógushoz, a tételhez kapcsolódó objektumokhoz vagy éppen a teljes szöveghez juthatunk el. A Példányok fül alatt van lehetőségünk a részletes elhelyezési adatokat megtekinteni. ${ }^{18} \mathrm{~A}$ rendszerbe való bejelentkezés után, innen és az Elöjegyzések fül alól is kezdeményezhetjük a példány elöjegyzését. ${ }^{19}$ A Szolgáltatások alatt az SFX linkfeloldásai érhetők el, amelyek révén az adott mü további elérhetőségeit fedezhetjük fel.

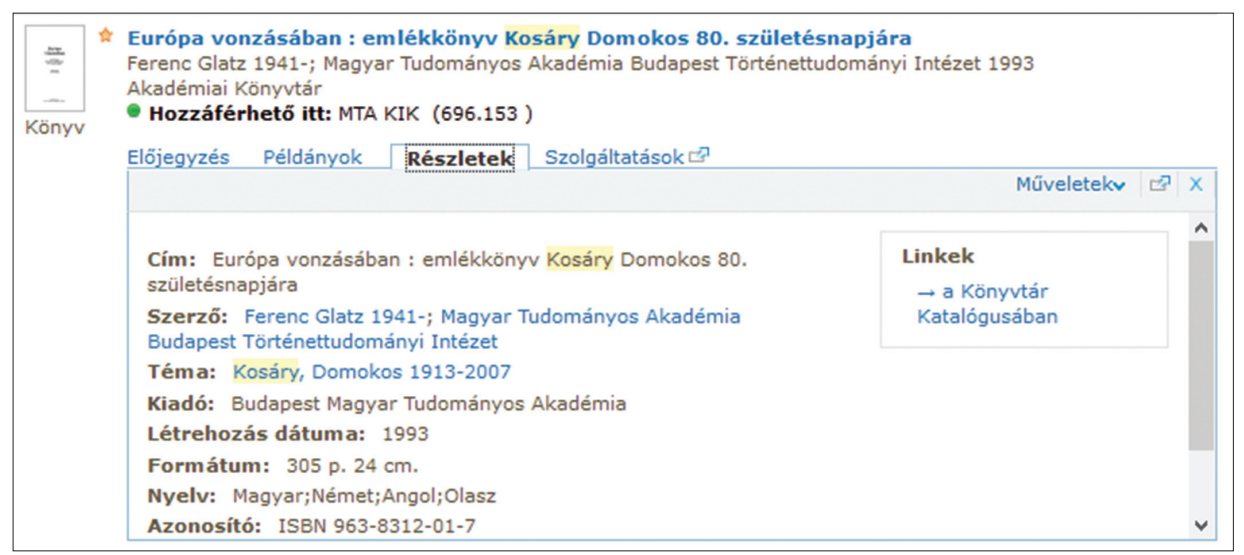

6. ábra. A tételhez kapcsolódó szolgáltatások és a Részletek ablak

A Primo ún. facetták révén meghatározott szempontok alapján csoportosíthatja a teljes találati listát, jelentősen megkönnyítve a felhasználó dolgát. A facetták a találati lista bal oldalán helyezkednek el, esetünkben a gyüjtemény, létrehozás dátuma ${ }^{20}$, nyelv, téma és alkotó lehetöségek vannak definiálva. Ezenkívül a találati halmazra építve szerző és tárgyszó alapján a témához illeszkedő új kereséseket is ajánl a rendszer. A nyitólapon egy-egy facettában néhány tétel jelenik meg, míg a További opciók linkre kattintva az egy csoporton belüli összes előfordulást látjuk.

${ }^{17} \mathrm{Az}$ alapadatok mellett itt már megtaláljuk a tárgyszólistát, vagy éppen a nyelvre, formátumra vonatkozó adatokat.

${ }^{18}$ Például raktári jelzet, vonalkód, példánystátusz.

${ }^{19} \mathrm{Az}$ elöjegyzés során csak az átvétel helyét kell maghatároznunk (Kölcsönzőpult, Olvasóterem).

${ }^{20}$ Ebben a facettában normalizálva sorolja be a találati listában szereplő dátumokat a rendszer. Az 1899 elötti dátumokat századra (1826 $\rightarrow$ 1800), az 1900-1949 közötti évszámokat tizedre $(1933 \rightarrow 1930)$ kerekíti, az 1950 utániakat viszont változatlanul hagyja a rendszer. 


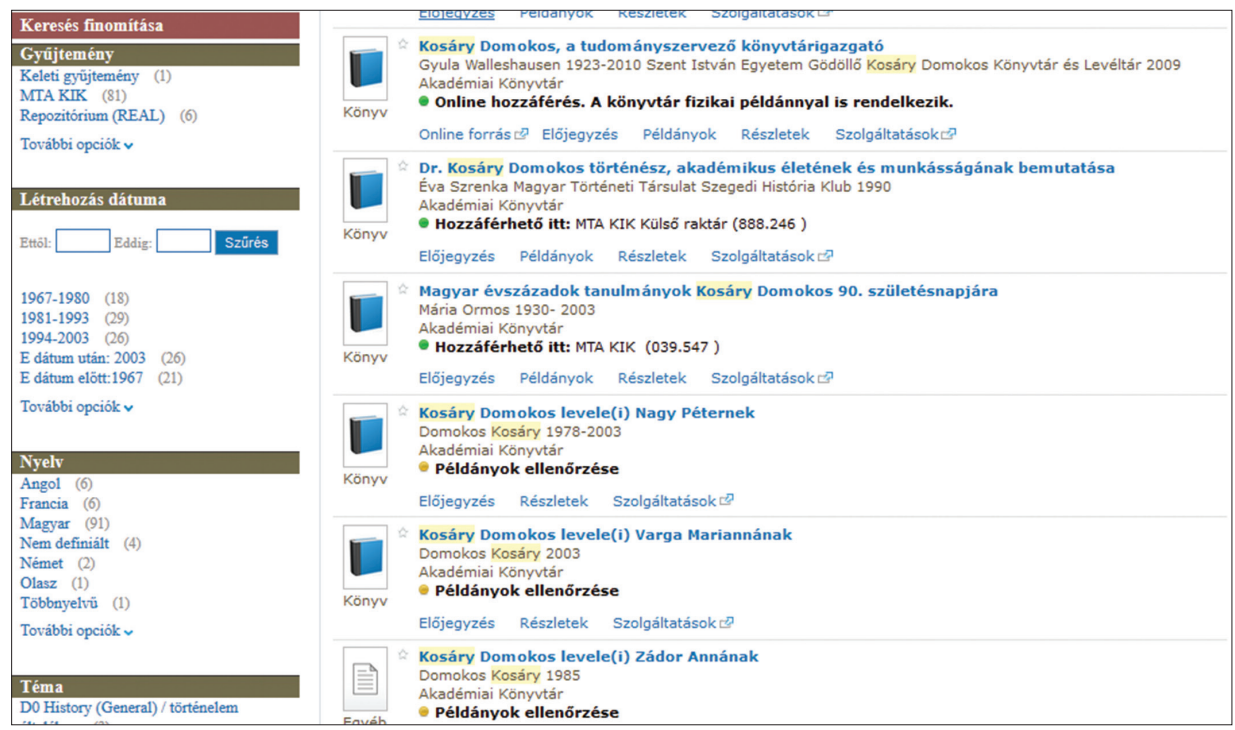

\section{7. ábra. Facetták}

A szoftver számos kényelmi szolgáltatást nyújt a felhasználóknak. Lehetőség van például a találatok egyenkénti és csoportos (teljes találati lap) mentésére, a keresőkérdés mentésekor témafigyelés beállítására, a találati listában megjelenő tételek nyomtatására vagy e-mailben való elküldésére, bibliográfiai szerkesztőprogramba (pl. EasyBib) exportálására, a rekord állandó linkjének (permalink) lekérésére, vagy a bibliográfiai adatokból különböző típusú idézetek szerkesztésére.

Bejelentkezés után igénybe vehetjük a rendszer e-Polc szolgáltatásait a keresés során elmentett dokumentumaink kezelésére, a kölcsönzési adataink ellenőrzésére, vagy saját adatbáziscsoportok kialakítására. A kereséskor elmentett tételeinknek a kosárban mappákat hozhatunk létre, amelyekkel tematikusan szortírozhatjuk őket a könnyebb áttekinthetőség érdekében. A tételeket egyesével, illetve csoportosan is menedzselhetjük innen is. Figyelemmel kísérhetjük kölcsönzéseinket, elöjegyzéseinket és pénzügyi adatainkat, lehetőségünk van kölcsönzéseink meghosszabbítására. Szintén az e-Polc-on tudunk az adatbázis A-Z listából választva saját adatbáziscsoportokat kialakítani, amelyek aztán a további keresések során önálló keresési tartományként müködnek. 


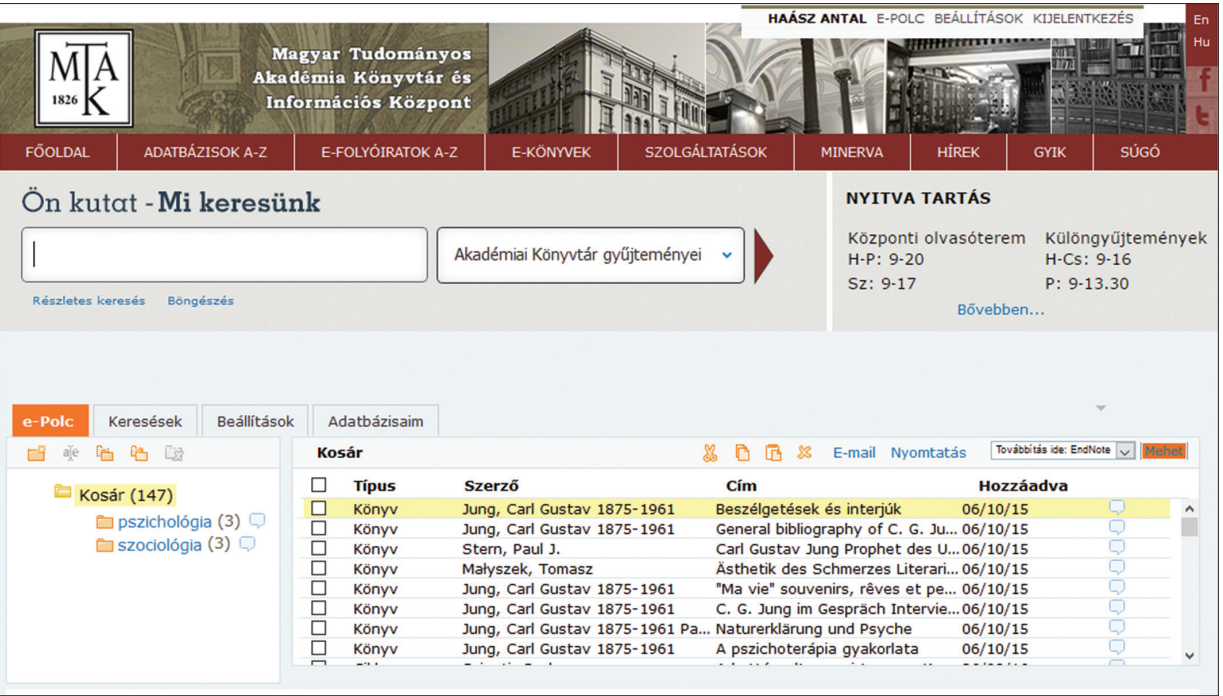

8. ábra. A Primo e-Polca

\begin{tabular}{|l|l|}
\hline Ön kutat - Mi keresünk \\
\hline Részletes keresés Böngészés \\
Miben kereshetek?
\end{tabular}

9. ábra. Saját keresőcsoport a keresési tartományok között

\section{Záró gondolatok}

Úgy gondolom, hogy egy megfelelő discovery rendszer megtalálása és alkalmazása, a felhasználói és technológiai igények nagymérvű megváltozása következtésben fontos és elengedhetetlen lépés minden fejlödni kívánó könyvtár életében. A döntés nem kis kockázattal jár: vajon a nem kis anyagi áldozatok árán megszerzett rendszer beváltja-e a hozzáfüzött reményeket? Képes lesz-e általa a könyvtár hatékonyan menedzselni elektronikus szolgáltatásait? Elnyeri-e a felhasználók tetszését? 
Az elmúlt közel másfél év tapasztalatai alapján az a személyes véleményem alakult ki, hogy - bár jelenleg is dolgozunk a hibák javításán és bizonyos szolgáltatások hatékonyabbá tételén, valamint további lépéseket kell tennünk a rendszer nagyobb használói elfogadottságáért - a Primo jó választásnak bizonyult az MTA KIK-ben. A rendszer képes az egyik legnagyobb tudományos szakkönyvtár információs vagyonának hatékony kezelésére, és annak eredményes közvetítésére a felhasználók felé.

\section{Rezümé}

A Primo egy felhőtechnológián alapuló discovery and delivery rendszer, amely képes biztosítani a könyvtári gyüjtemények teljes körủ és intuitív visszakereshetőségét. Az MTA KIK közel 1 éves bevezetési fázis után 2015 novemberében nyitotta meg a rendszer használatát felhasználói elött. A tesztidőszak alatt megoldásra kerültek a legfontosabb technikai és tartalmi problémák. A szolgáltatás nyitóoldala egyben a könyvtár szolgáltatási felülete is. Ennek megfelelően az aktualitás hírek mellett a keresőrendszerekkel és a dokumentumszolgáltatással kapcsolatos információk kaptak helyet az oldalon. A kereséshez hat keresőcsoport lett meghatározva: a könyvtár katalógusa, képkönyvtára, repozitóriuma és előfizetett adatbázisai (illetve egyéb szabadon elérhető források) mellett az akadémiai intézetek és fontosabb országos katalógusok rekordjai, rész- és teljes szövegủ dokumentumai kereshetők le a rendszerben. A tanulmány képernyőképekkel illusztrálva, részletesen ismerteti a szoftver müködését: a különböző keresési lehetőségeket, a találati lista szerkezetét, az adatmegjelenítést és példánykezelést. Az írás emellett kitér a találati halmaz csoportosítását végző facetták, és az elérhető kényelmi szolgáltatások bemutatásra is. Végezetül a szerző - az elmúlt közel másfél év tapasztalatának tükrében - néhány sorban értékeli a szoftver használhatóságát egy tudományos szakkönyvtár életében.

\section{Using Primo in the Library and Information Centre of the Hungarian Academy of Sciences}

Primo is a cloud technology based discovery and delivery system that can provide the full and intuitive retrieval of library collections. In November 2015, after almost 1 year test period the library made the system accessible for the users. During the test period the most important technical and database problems were solved. The home page of the service is the interface of the services of the library at the same time. Accordingly the latest news, information regarding the query system and the document delivery services are located on the page. Six scopes were defined for the search: the catalogue, the image collection and the repository of the library, the subscribed databases (and a few free one), the catalogues of the institutions of the academy and some main national catalogues with their full text documents. The paper illustrated with screenshots presents in detail the operation of the software: the different ways of searching, the structure of the search result lists, the data view and the copy management. Besides the paper presents the facets 
that group the results and the available convenience options, too. In the last few lines the author - summing up the experiences of the last one and a half year - evaluates the usefulness of the software in a scientific research library.

HAÁSZ ANTAL osztályvezető-helyettes MTA KIK Szakinformatikai Osztály 